\title{
Vibration-induced reversal of spontaneous nystagmus in lateral medullary infarction
}

回

Figure Acute lateral medullary infarction

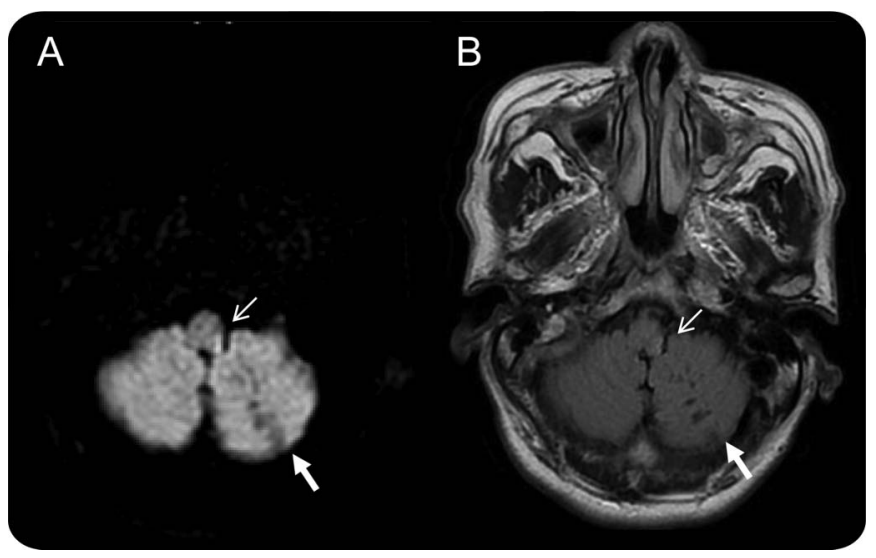

Brain MRI shows an acute infarct (thin arrows) in the left lateral medulla on diffusion-weighted imaging (A) and fluidattenuated inversion recovery (B). There are also multiple old infarcts (thick arrows) in the left cerebellar hemisphere.

Supplemental data at www.neurology.org
A 68-year-old man developed vertigo with a lateral medullary syndrome (figure). Right-beating nystagmus, seen under Frenzel lenses, reversed when a vibrator $(60 \mathrm{~Hz})$ was applied on either sternocleidomastoid muscle or either mastoid. When the vibrator was turned off, the nystagmus returned to right-beating (video on the Neurology ${ }^{\circledR}$ Web site at www.neurology.org).

Vibration-induced nystagmus, usually beating toward the intact side, is seen in unilateral peripheral vestibulopathy. ${ }^{1}$ We describe a patient with lateral medullary infarction in whom vibration reversed the spontaneous nystagmus, a pattern differing from that typically seen with peripheral lesions. ${ }^{2}$ This finding implies that a central vestibular nystagmus may be altered by labyrinthine or nuchal proprioceptic stimulation.

\section{Tzu-Pu Chang, $M D$, Yi-Chang $W u$, $M D$}

From the Department of Neurology (T.-P.C.), Neuro-Medical Scientific Center, Buddhist Tzu Chi General Hospital, Taichung Branch; and Antien ENT Clinic (Y.-C.W.), Tainan, Taiwan.

Author contributions: T.-P. Chang: drafting/revising the manuscript. Y.-C. Wu: study concept or design.

Acknowledgment: The authors thank Prof. David Zee for critically reviewing the manuscript.

Study funding: No targeted funding reported.

Disclosure: The authors report no disclosures relevant to the manuscript. Go to Neurology.org for full disclosures.

Correspondence to Dr. Chang: neurochang0617@gmail.com

1. Dumas G, Karkas A, Perrin P, Chahine K, Schmerber S. High-frequency skull vibration-induced nystagmus test in partial vestibular lesions. Otol Neurotol 2011;32:1291-1301.

2. Choi KD, Oh SY, Park SH, Kim JH, Koo JW, Kim JS. Head-shaking nystagmus in lateral medullary infarction: patterns and possible mechanisms. Neurology 2007;68:1337-1344. 


\section{Neurology}

\section{Vibration-induced reversal of spontaneous nystagmus in lateral medullary infarction Tzu-Pu Chang and Yi-Chang $\mathrm{Wu}$ \\ Neurology 2013;80;1353 \\ DOI 10.1212/WNL.0b013e31828ab336}

\section{This information is current as of April 1, 2013}

Updated Information \& Services

Supplementary Material

References

Subspecialty Collections

Permissions \& Licensing

Reprints including high resolution figures, can be found at: http://n.neurology.org/content/80/14/1353.full

Supplementary material can be found at: http://n.neurology.org/content/suppl/2013/03/30/80.14.1353.DC1

This article cites 2 articles, 1 of which you can access for free at: http://n.neurology.org/content/80/14/1353.full\#ref-list-1

This article, along with others on similar topics, appears in the following collection(s):

All Neurotology

http://n.neurology.org/cgi/collection/all_neurotology

Nystagmus

http://n.neurology.org/cgi/collection/nystagmus

Vertigo

http://n.neurology.org/cgi/collection/vertigo

Information about reproducing this article in parts (figures,tables) or in its entirety can be found online at:

http://www.neurology.org/about/about_the_journal\#permissions

Information about ordering reprints can be found online:

http://n.neurology.org/subscribers/advertise

Neurology ${ }^{\circledR}$ is the official journal of the American Academy of Neurology. Published continuously since 1951, it is now a weekly with 48 issues per year. Copyright (O) 2013 American Academy of Neurology. All rights reserved. Print ISSN: 0028-3878. Online ISSN: 1526-632X.

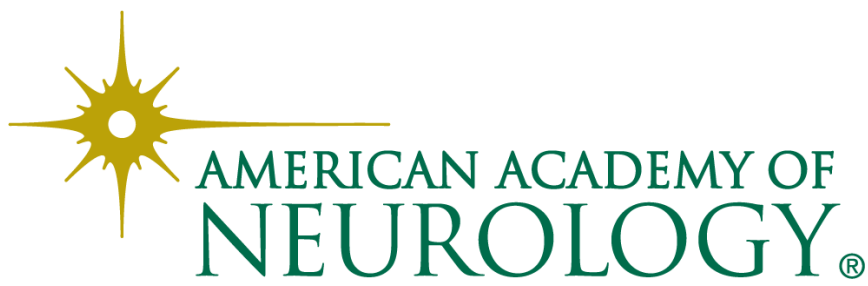

